\title{
Assessment of Trace Elements in Soils and Sediments in the Abandoned Mercury Mine Site in Puerto Princesa City, Philippines
}

\author{
Jessie Samaniego ${ }^{1, *}$, Cris Reven Gibaga $^{1}$, Alexandria Tanciongco ${ }^{1}$, and Rasty Rastrullo ${ }^{1}$ \\ ${ }^{1}$ Department of Science and Technology, Philippine Nuclear Research Institute, Commonwealth Ave., Quezon City, 1101, Philippines \\ *Corresponding author: mailto:josamaniego@pnri.dost.gov.ph
}

\author{
KEYWORDS \\ Abandoned mine \\ Mercury \\ Rare earth elements \\ Heavy metals \\ Palawan \\ SUBMITTED 18 March 2021 \\ REVISED 21 June 2021 \\ ACCEPTED 22 June 2021
}

\begin{abstract}
An abandoned mercury mine area in Puerto Princesa City, which was previously operated by Palawan Quicksilver Mines, Inc. (PQMI) from 1953 to 1976, is known for its unrehabilitated open-pit of mercury-rich rocks and exposed mine waste calcine stockpiles in the vicinity. In order to establish an understanding on the geology of the abandoned mercury mine deposit and to obtain clues in determining the possible metal pollutants in the area, measurement of trace element concentrations of soil and sediments collected from the PQMI vicinity were conducted. Soil and sediment samples were analyzed for heavy metals, rare-earth elements and naturally occurring radioactive elements and determined its contamination factor as part of risk assessment. Analytical results showed that aside from mercury, several heavy metals (nickel, chromium, manganese) were found to be anomalous due to the geology of the area. Statistical analyses show that chromium, nickel and antimony present the highest contamination factor among the sampling groups. Mercury is found to have negative bias with higher rare earth elements concentration but positively correlated with arsenic, antimony, and thallium. In general, there is low concentration of rare earth elements (except for scandium) in comparison with its respective average crustal concentration. Due to the nature of geology in the area, naturally occurring radioactive elements influence is also minimal. The results of this study, especially on the assessment of soil and sediment pollutants, are recommended as guidance to its mine rehabilitation.
\end{abstract}

(c) The Author(s) 2021. This article is distributed under a Creative Commons Attribution-ShareAlike 4.0 International license.

\section{INTRODUCTION}

The Philippines, with its geological nature, hosts several economic metallic deposits, some of which were extracted by private mining companies. Mining wastes are rampant in several areas that are not environmentally monitored, especially in abandoned mine sites (Samaniego et al. 2020b). One of these metallic deposits that was not rehabilitated after its mining period is found in Puerto Princesa City in the island of Palawan. Palawan Island is geologically divided into two main tectonic blocks; the North Palawan Block and South Palawan Block (Suggate et al. 2014). The lithologies in Puerto Princesa City are part of South Palawan Block, which include Palawan Ophiolite (ultramafics Block) and the South Palawan Block (Gibaga et al. 2020). The Northern Palawan Block contains old continental rocks rifted from mainland China after the opening of the South China Sea (Aurelio et al. 2014; Suggate et al. 2014; Padrones et al. 2017), while the South Palawan Block is dominated by ophiolite derived from an ocean basin believed to be of Cretaceous age that was thrusted to the present day Palawan Island (Yumul et al. 2009; Suggate et al. 2014; Gibaga et al. 2020). Puerto Princesa City is underlain by Palawan Ophiolite (ultramafics, gabbros, and basalts), Iwahig Formation (Pliocene limestone and conglomerates), and Tagburos Opalite (Peña 2008). The Tagburos Opalite, which is the youngest lithology in South Palawan Block, refers to the yel- lowish to mocha brown siliceous rocks presumed to have been deposited during the Pleistocene (Williams et al. 1999). This opalite body is surrounded by serpentinized ultramafic rocks of Palawan Ophiolite to the north and is overlain by conglomerate-sandstone beds of Iwahig Formation to the south and quaternary alluvium to the east (Antonio et al. 1976). The origin of several hot springs in Puerto Princesa City is still a subject of discussion, but it is believed to be related to the hydrothermal fluids that brought forth the mercury (Hg) mineralization in central Palawan (Peña 2008).

The only naturally occurring deposit of Hg in the Philippines can be found in Puerto Princesa City. It mostly occurs in cinnabar (HgS) ores hosted by opalite bodies deposited along fractures and weak zones in the bedrock (Williams et al. 1999). The Hg deposit which is located in the village of Santa Lourdes in Puerto Princesa City was owned and operated by the Palawan Quicksilver Mines, Inc. (PQMI) from 1953 to 1976. It has $\mathrm{Hg}$ grades of as high as $10.65 \mathrm{lbs} /$ ton (Zerda 1972). The Hg mining in the area was stopped due to the declining price of $\mathrm{Hg}$ in the world market in the 1970s. Due to the abandonment and lack of rehabilitation in the mine site, Hg contamination in soils, sediments and water is a prevailing issue in the surrounding community. While Hg assessment and characterization studies have been conducted in the past on this abandoned mine site, the extent of contamination by other trace elements in relaion with its geology has not been evaluated. This study aims to char- 
acterize the trace elements (heavy metals, rare earth elements, and naturally occurring radioactive elements) in the soils and sediments to have an understanding on their behavior in the abandoned PQMI mine site and to have clues in determining $\mathrm{Hg}$ contamination.

\section{MATERIALS AND METHODS}

\subsection{Study area}

The study area, Puerto Princesa City, is located in the central portion of Palawan Island in the Philippines (Figure 1). Specific study area is situated about $14 \mathrm{~km}$ north of Puerto Princesa City proper $\left(118^{\circ} 43^{\prime} \mathrm{N}, 9^{\circ} 50^{\prime} \mathrm{E}\right)$, and encompasses two villages: Santa Lourdes and Tagburos. The former open pit area is traversed by Tagburos River, which drains to Honda Bay coast, a local fishing area and tourist spot. In this area, the Hg deposit in the form of cinnabar is hosted by Tagburos Opalite formation. The opalite rocks were observed as veins cutting the weathered ultramafic bedrock and cinnabar was found to have precipitated in cavities and linings of the siliceous vein. After abandonment of the PQMI mine site, the open pit was naturally filled with water and now forming a lake.

\subsection{Soil and sediment sampling}

A total of 33 soil and sediment samples were collected from September 2018 to July 2019 within the vicinity of the PQMI area from seven (7) sampling groups, namely: a pit lake, Tagburos River, Honda Bay wharf, Honda Bay, mine waste calcine, other rivers, and surrounding soils (Figure 1, Table 1). Six (6) soil samples were collected from the vicinity of the mining site, while nine (9) surface sediments were collected from Tagburos River, and four (4) from other nearby rivers not traversing the pit lake in the area. A representative mine waste calcine sample was collected from the stockpile near the pit lake and from the scattered calcines situated $500 \mathrm{~m}$ northeast of the pit lake. From the coastline of Honda Bay, six (6) samples were collected, along with another three (3) from the nearby wharf. Lastly, five (5) soils from roadcuts and/or exposures were also obtained from the surrounding vicinity.

Samples were collected using a plastic trowel, from the top $10 \mathrm{~cm}$ of the soil surface and surface sediment of rivers and were placed in polyethylene resealable plastic bags. All samples were prepared by air-drying and sieving up to U.S.

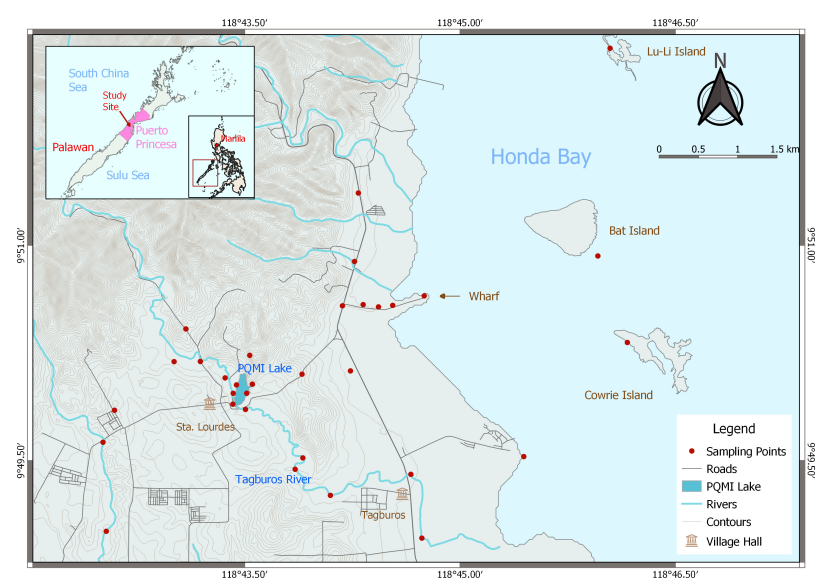

FIGURE 1. Location map of sampled points for trace elements and mercury near the abandoned PQMI mine area. Inset shows location of study area with respect to Philippine map.
Standard 230 mesh $(63 \mu \mathrm{m})$, to separate the silt-clay $(<63$ $\mu \mathrm{m})$ size particles from the sand fraction. Only the $<63 \mu \mathrm{m}$ fractions were analyzed for $\mathrm{Hg}$ and trace element contents to minimize sediment size bias.

\subsection{Elemental analyses}

All soil and sediment samples were analyzed for trace elements, including heavy metals, rare earth elements (REEs) and naturally occurring radioactive elements using Inductively Coupled Plasma - Mass Spectrometry (ICP-MS; Agilent Technologies, USA). A sample of around $1 \mathrm{~g}$ was prepared using a multi-acid (4-acid) digestion procedure that included dissolution in hot nitric acid $\left(\mathrm{HNO}_{3}\right)$ followed by mixture of hydroflouric acid (HF), perchloric acid $\left(\mathrm{HClO}_{4}\right)$, and hydrochloric acid $(\mathrm{HCl})$ to stabilize elements as an ionic solution. Multi-element certified reference material (OREAS 44P) was digested and analyzed along with samples to serve as quality control.

Total Hg concentration in soil and sediments was determined using a direct mercury analyzer DMA-80 evo (Milestone Srl, Italy) following the U.S. EPA Method 7473

TABLE 1. Soil and sediments sampling locations in PQMI and vicinities and its descriptions.

\begin{tabular}{|c|c|c|}
\hline $\begin{array}{l}\text { Sampling } \\
\text { point }\end{array}$ & Coordinates & Sampling group \\
\hline 1 & $9^{\circ} 52^{\prime} 50.87^{\prime \prime} \mathrm{N}, 118^{\circ} 44^{\prime} 49.92^{\prime \prime} \mathrm{E}$ & Honda Bay sediment \\
\hline 2 & $9^{\circ} 52^{\prime} 22.43^{\prime \prime} \mathrm{N}, 118^{\circ} 46^{\prime} 2.72^{\prime \prime} \mathrm{E}$ & Honda Bay sediment \\
\hline 3 & $9^{\circ} 50^{\prime} 55.56^{\prime \prime} \mathrm{N}, 118^{\circ} 45^{\prime} 57.61^{\prime \prime} \mathrm{E}$ & Honda Bay sediment \\
\hline 4 & $9^{\circ} 50^{\prime} 19.38^{\prime \prime} \mathrm{N}, 118^{\circ} 46^{\prime} 9.93^{\prime \prime} \mathrm{E}$ & Honda Bay sediment \\
\hline 5 & $9^{\circ} 49^{\prime} 31.66^{\prime \prime} \mathrm{N}, 118^{\circ} 45^{\prime} 26.65^{\prime \prime} \mathrm{E}$ & Honda Bay sediment \\
\hline 6 & $9^{\circ} 47^{\prime} 54.11^{\prime \prime} \mathrm{N}, 118^{\circ} 46^{\prime} 21.27^{\prime \prime} \mathrm{E}$ & Honda Bay sediment \\
\hline 7 & $9^{\circ} 50^{\prime} 35.22^{\prime \prime} \mathrm{N}, 118^{\circ} 44^{\prime} 19.51^{\prime \prime} \mathrm{E}$ & Honda Bay wharf \\
\hline 8 & $9^{\circ} 50^{\prime} 34.27^{\prime \prime} \mathrm{N}, 118^{\circ} 44^{\prime} 25.91^{\prime \prime} \mathrm{E}$ & Honda Bay wharf \\
\hline 9 & $9^{\circ} 50^{\prime} 34.9^{\prime \prime} \mathrm{N}, 118^{\circ} 44^{\prime} 31.86^{\prime \prime} \mathrm{E}$ & Honda Bay wharf \\
\hline 10 & $9^{\circ} 50^{\prime} 14^{\prime \prime} \mathrm{N}, 118^{\circ} 43^{\prime} 32.1^{\prime \prime} \mathrm{E}$ & Mine waste calcine \\
\hline 11 & $9^{\circ} 49^{\prime} 37.65^{\prime \prime} \mathrm{N}, 118^{\circ} 42^{\prime} 30.77^{\prime \prime} \mathrm{E}$ & Other rivers \\
\hline 12 & $9^{\circ} 50^{\prime} 53.26^{\prime \prime} \mathrm{N}, 118^{\circ} 44^{\prime} 15.89^{\prime \prime} \mathrm{E}$ & Other rivers \\
\hline 13 & $9^{\circ} 50^{\prime} 34.72^{\prime \prime} \mathrm{N}, 118^{\circ} 44^{\prime} 10.84^{\prime \prime} \mathrm{E}$ & Other rivers \\
\hline 14 & $9^{\circ} 49^{\prime} 0.42^{\prime \prime} \mathrm{N}, 118^{\circ} 42^{\prime} 32.14^{\prime \prime} \mathrm{E}$ & Other rivers \\
\hline 15 & $9^{\circ} 50^{\prime} 1.64^{\prime \prime} \mathrm{N}, 118^{\circ} 43^{\prime} 26.56^{\prime \prime} \mathrm{E}$ & Pit lake \\
\hline 16 & $9^{\circ} 49^{\prime} 58.11^{\prime \prime} \mathrm{N}, 118^{\circ} 43^{\prime} 25.19^{\prime \prime} \mathrm{E}$ & Pit lake \\
\hline 17 & $9^{\circ} 49^{\prime} 58.15^{\prime \prime} \mathrm{N}, 118^{\circ} 43^{\prime} 30.84^{\prime \prime} \mathrm{E}$ & Pit lake \\
\hline 18 & $9^{\circ} 50^{\prime} 1.94^{\prime \prime} \mathrm{N}, 118^{\circ} 43^{\prime} 33.2^{\prime \prime} \mathrm{E}$ & Pit lake \\
\hline 19 & $9^{\circ} 50^{\prime} 7.5^{\prime \prime} \mathrm{N}, 118^{\circ} 44^{\prime} 14.2^{\prime \prime} \mathrm{E}$ & Surrounding soils \\
\hline 20 & $9^{\circ} 50^{\prime} 11.37^{\prime \prime} \mathrm{N}, 118^{\circ} 43^{\prime} 0.48^{\prime \prime} \mathrm{E}$ & Surrounding soils \\
\hline 21 & $9^{\circ} 49^{\prime} 51.04^{\prime \prime} \mathrm{N}, 118^{\circ} 42^{\prime} 35.6^{\prime \prime} \mathrm{E}$ & Surrounding soils \\
\hline 22 & $9^{\circ} 51^{\prime} 21.89^{\prime \prime} \mathrm{N}, 118^{\circ} 44^{\prime} 17.5^{\prime \prime} \mathrm{E}$ & Surrounding soils \\
\hline 23 & $9^{\circ} 50^{\prime} 6.12^{\prime \prime} \mathrm{N}, 118^{\circ} 43^{\prime} 53.96^{\prime \prime} \mathrm{E}$ & Surrounding soils \\
\hline 24 & $9^{\circ} 50^{\prime} 11.46^{\prime \prime} \mathrm{N}, 118^{\circ} 43^{\prime} 11.45^{\prime \prime} \mathrm{E}$ & Tagburos River \\
\hline 25 & $9^{\circ} 49^{\prime} 15.44^{\prime \prime} \mathrm{N}, 118^{\circ} 44^{\prime} 5.81^{\prime \prime} \mathrm{E}$ & Tagburos River \\
\hline 26 & $9^{\circ} 49^{\prime} 31.12^{\prime \prime} \mathrm{N}, 118^{\circ} 43^{\prime} 54.31^{\prime \prime} \mathrm{E}$ & Tagburos River \\
\hline 27 & $9^{\circ} 50^{\prime} 6.12^{\prime \prime} \mathrm{N}, 118^{\circ} 43^{\prime} 53.96^{\prime \prime} \mathrm{E}$ & Tagburos River \\
\hline 28 & $9^{\circ} 49^{\prime} 26.35^{\prime \prime} \mathrm{N}, 118^{\circ} 43^{\prime} 51.08^{\prime \prime} \mathrm{E}$ & Tagburos River \\
\hline 29 & $9^{\circ} 49^{\prime} 24.24^{\prime \prime} \mathrm{N}, 118^{\circ} 44^{\prime} 39.45^{\prime \prime} \mathrm{E}$ & Tagburos River \\
\hline 30 & $9^{\circ} 48^{\prime} 57.56^{\prime \prime} \mathrm{N}, 118^{\circ} 44^{\prime} 44.05^{\prime \prime} \mathrm{E}$ & Tagburos River \\
\hline 31 & $9^{\circ} 49^{\prime} 53.58^{\prime \prime} \mathrm{N}, 118^{\circ} 43^{\prime} 25.06^{\prime \prime} \mathrm{E}$ & Tagburos River \\
\hline 32 & $9^{\circ} 50^{\prime} 4.58^{\prime \prime} \mathrm{N}, 118^{\circ} 43^{\prime} 21.81^{\prime \prime} \mathrm{E}$ & Tagburos River \\
\hline 33 & $9^{\circ} 49^{\prime} 51.38^{\prime \prime} \mathrm{N}, 118^{\circ} 43^{\prime} 30.34^{\prime \prime} \mathrm{E}$ & Tagburos River \\
\hline
\end{tabular}


(mercury in solids and solutions by thermal decomposition, amalgamation, and atomic absorption spectroscopy). Soil samples were weighed $(0.10 \mathrm{~g})$ and placed in a nickel boat without any pre-treatment. The boat is then introduced to the direct mercury analyzer where it is initially dried at up to $250^{\circ} \mathrm{C}$, and then thermally decomposed at $900^{\circ} \mathrm{C}$ in a continuous flow of oxygen. The total $\mathrm{Hg}$ content is determined using atomic absorption spectrometry at $254 \mathrm{~nm}$. Mercury analysis results from DMA-80 were validated using certified reference material for stream sediments (GSD1) prepared by the Institute of Geophysical and Geochemical Exploration of China.

\subsection{Risk assessment of soil and sediment pollution}

Heavy metal contamination for each sampling group was identified by calculating the contamination factor $\left(C_{f}^{i}\right)$ of each element following the procedure proposed by Hakanson (1980). The contamination factor is a heavy metal index derived by simply getting the ratio of the concentration of the metal in the sample $\left(C_{0-1}^{i}\right)$ and its average upper crustal background level $\left(C_{n}^{i}\right)$, as shown in Equation 1.

$$
C_{f}^{i}=\frac{C_{0-1}^{i}}{C_{n}^{i}}
$$

Values for upper crustal average for the heavy metals were based on the work of Taylor (1964), as presented in Table 2. There are four classes of contamination levels recognized by Hakanson (1980): (i) Low contamination factor for $C_{f}^{i}<1$, (ii) Moderate contamination factor for $1<C_{f}^{i}<3$, (iii) considerable contamination factor for $3<C_{f}^{i}<6$, and (iv) very high contamination factor for $C_{f}^{i}>6$. Spearman's correlation coefficient was used in detecting the relationships among the trace metals analyzed.

\section{RESULTS AND DISCUSSION}

\subsection{Anomalous concentrations of $\mathrm{Hg}, \mathrm{Ni}, \mathrm{Cr}$, and $\mathrm{Mn}$ in $\mathrm{PQMI}$ rocks}

The analytical results of heavy metal analysis for the soil and sediment sampling at the abandoned PQMI mine area are given in Table 2. It was observed that there are anomalous concentrations of $\mathrm{Hg}$, nickel (Ni), chromium (Cr), and manganese (Mn) for most sampling groups. Ni and $\mathrm{Cr}$ are highest in both sediments obtained in the vicinity of pit lake and in the mine waste calcines, while Mn is elevated in Tagburos River and nearby rivers. Hg is particularly high in Honda Bay wharf and in the mine waste calcine.

The anomalous concentration of these heavy metals can be inferred by inspecting the general geology of Puerto Princesa City, particularly following the lithology traversed by the Tagburos River (Figure 1). The presence of ultramafic rocks of Palawan Ophiolite in the upstream portion of Tagburos River can explain the high $\mathrm{Cr}$ and Ni concentrations while the high Mn content of the sediment samples can be attributed to the occurrence of interbedded red chert and dark manganiferous chert in the former Sulu Sea mine located approximately $4 \mathrm{~km}$ northeast of the pit lake. High $\mathrm{Hg}$ content in Honda Bay wharf is caused by the mine waste calcine being used in the construction of the wharf (Gray et al. 2003; Samaniego et al. 2020a). The $600 \mathrm{~m}$ long wharf previously served as a port for $\mathrm{Hg}$ mining operations and now serves as a port for tourist and fishing boats.

TABLE 2. Heavy metal concentrations of sediment samples collected in different sapling groups in the vicinity of abandoned PQMI mine area.

\begin{tabular}{|c|c|c|c|c|c|c|c|c|}
\hline $\begin{array}{l}\text { Trace } \\
\text { element }\end{array}$ & Pit lake & $\begin{array}{l}\text { Tagburos } \\
\text { River }\end{array}$ & $\begin{array}{l}\text { Honda Bay } \\
\text { wharf }\end{array}$ & Honda Bay & $\begin{array}{l}\text { Mine waste } \\
\text { calcine }\end{array}$ & Other rivers & $\begin{array}{l}\text { Surrounding } \\
\text { soils }\end{array}$ & $\begin{array}{l}\text { Crustal } \\
\text { average* }^{*}\end{array}$ \\
\hline $\mathrm{n}$ & 4 & 9 & 3 & 6 & 1 & 4 & 6 & \\
\hline $\mathrm{Al}(\%)$ & 2.19 & 3.00 & 0.75 & 0.61 & 2.55 & 2.92 & 2.97 & 8.23 \\
\hline As $(\mathrm{mg} / \mathrm{kg})$ & 7.75 & 4.89 & 50.67 & 16.33 & 4.00 & 5.75 & 5.75 & 1.80 \\
\hline $\mathrm{Ba}(\mathrm{mg} / \mathrm{kg})$ & 29.50 & 52.11 & 29.33 & 7.50 & 20.00 & 47.75 & 38.33 & 425.00 \\
\hline $\mathrm{Bi}(\mathrm{mg} / \mathrm{kg})$ & $<0.05$ & $<0.05$ & 0.38 & $<0.05$ & 0.07 & 0.098 & 0.08 & 0.17 \\
\hline $\mathrm{Cd}(\mathrm{mg} / \mathrm{kg})$ & 0.21 & 0.28 & 0.34 & 0.21 & 0.03 & 0.18 & 0.16 & 0.20 \\
\hline Co $(\mathrm{mg} / \mathrm{kg})$ & 124.70 & 98.52 & 27.70 & 33.67 & 131.10 & 119.25 & 111.00 & 25.00 \\
\hline $\mathrm{Cr}(\mathrm{mg} / \mathrm{kg})$ & 1479.75 & 513.33 & 1164.33 & 205.00 & 2972.00 & 514.75 & 731.67 & 100.00 \\
\hline $\mathrm{Cu}(\mathrm{mg} / \mathrm{kg})$ & 58.72 & 83.57 & 116.87 & 60.28 & 46.00 & 67.45 & 50.72 & 55.00 \\
\hline $\mathrm{Fe}(\%)$ & 13.87 & 7.67 & 16.15 & 2.96 & 23.29 & 9.17 & 10.81 & 5.63 \\
\hline $\mathrm{Ga}(\mathrm{mg} / \mathrm{kg})$ & 5.32 & 8.44 & 3.95 & 1.45 & 7.00 & 8.20 & 7.98 & 15.00 \\
\hline $\mathrm{Hg}(\mathrm{mg} / \mathrm{kg})$ & 193.72 & 26.40 & 397.24 & 1.56 & 171.20 & 10.14 & 5.04 & 0.08 \\
\hline $\mathrm{Mn}(\mathrm{mg} / \mathrm{kg})$ & 860.50 & 2559.44 & 267.67 & 270.67 & 517.00 & 1922.75 & 1751.00 & 950.00 \\
\hline Mo (mg/kg) & 0.85 & 0.67 & 2.20 & 1.77 & 0.70 & 0.45 & 0.47 & 1.50 \\
\hline $\mathrm{Ni}(\mathrm{mg} / \mathrm{kg})$ & 2530.75 & 904.22 & 414.67 & 361.67 & 2202.00 & 2019.75 & 1375.17 & 75.00 \\
\hline $\mathrm{Pb}(\mathrm{mg} / \mathrm{kg})$ & 18.50 & 33.67 & 36.40 & 10.52 & 2.90 & 10.90 & 11.95 & 12.50 \\
\hline $\mathrm{Sb}(\mathrm{mg} / \mathrm{kg})$ & 3.38 & 2.46 & 30.18 & 4.32 & 4.25 & 1.14 & 0.77 & 0.20 \\
\hline Sn (mg/kg) & 23.22 & 1.61 & 3.93 & $<0.50$ & 0.50 & 1.175 & $<0.50$ & 2.00 \\
\hline $\mathrm{Sr}(\mathrm{mg} / \mathrm{kg})$ & 17.55 & 30.13 & 70.20 & 2747.58 & 2.70 & 21.90 & 18.97 & 375.00 \\
\hline Tl (mg/kg) & 1.88 & 0.15 & 20.08 & $<0.08$ & 1.41 & 0.17 & 0.14 & 0.45 \\
\hline $\mathrm{V}(\mathrm{mg} / \mathrm{kg})$ & 103.00 & 159.89 & 112.67 & 27.50 & 105.00 & 140.00 & 135.50 & 135.00 \\
\hline W (mg/kg) & $<0.10$ & $<0.10$ & 1.20 & 0.17 & 0.50 & 0.70 & $<0.10$ & 1.5 \\
\hline Zn (mg/kg) & 99.25 & 109.22 & 114.00 & 37.00 & 45.00 & 88.00 & 63.33 & 70.00 \\
\hline
\end{tabular}

*Taylor (1964) 
The heavy metals generally showing very high contamination factors in the area were $\mathrm{Cr}, \mathrm{Ni}$, and antimony (Sb). Those with considerable degrees of contamination included arsenic (As), cobalt (Co), and thallium (Tl). Due to the naturally high background of $\mathrm{Hg}$ in the area, its contamination factor expectedly reached very high values, ranging 44-4,466 (not included in Figure 2). All other analyzed heavy metals had $C_{f}^{i}<3$ for almost all sampling groups, indicating a low probability of them becoming pollutants.

\subsection{Rare earth elements and radioactive element concentrations in $\mathrm{Hg}$ deposits}

From the results of the REEs and radioactive elements analysis of sediment samples obtained in the vicinity of the pit lake, it was found that there is generally a low concentration of REEs and radioactive elements for all sampling groups in comparison with average crustal concentrations (Figure 3, Table 3). The average amount of light rare earth elements (LREE); lanthanum (La), cerium (Ce), praseodymium (Pr), neodymium (Nd), and samarium (Sm) were particularly very small in comparison with the crustal average, as well as uranium (U) and thorium (Th). There is an observed overall decrease in the concentration of elements, from La to lutetium (Lu), with increasing atomic weight. Only the average value of scandium (Sc) for all samples is higher than the crustal average, which can be attributed to laterite formation of the bedrock in the Puerto Princesa City area.

By contrasting the analyzed content in the sampling groups, the sediments obtained from Honda Bay wharf, Honda Bay, and mine waste have generally less REE than that from the pit lake and rivers (Figure 3). The sediments obtained in the periphery of the pit lake, and the sediments in Tagburos River and other tributaries can be representative of the concentration of original ultramafic bedrock of Puerto Princesa City. By normalization of the REE values of the pit lake and rivers with that of Carbonaceous Ivuna (CI) chondrite, there is a general trend of LREE enrichment and heavy rare earth elements (HREE) depletion with a slightly negative europium (Eu) anomaly (Figure 4). This behavior is similar to the REE trend observed in ultramafic rocks of ophiolite bodies in Naga Hills Ophiolite in India (Dey et al. 2018), Samail Ophiolite in Oman (Pallister and Knight 1981), and Zagros Ophiolite in Iran (Moghadam and Stern 2011).

Similarly, by normalizing the REE values with the crustal average, the enrichment and depletion pattern of

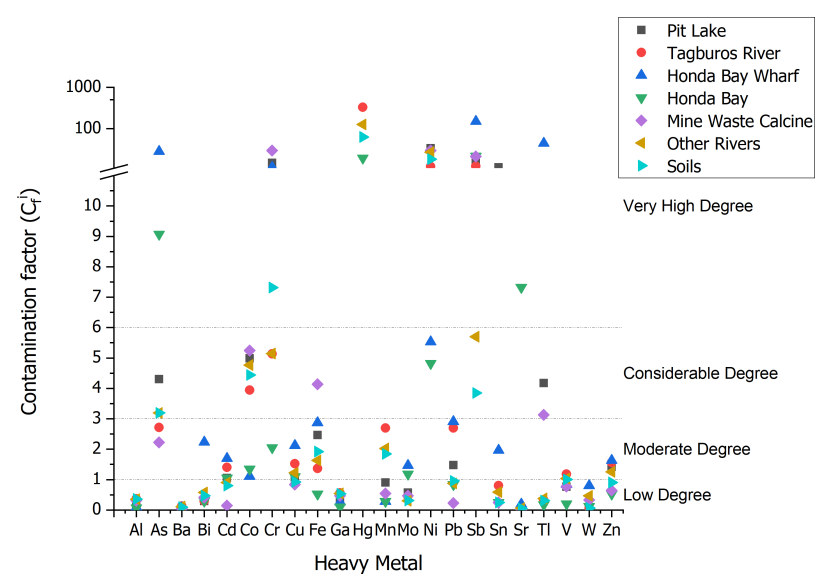

FIGURE 2. Contamination factor calculated for each heavy metal for each sampling group. elements can be observed with respect to alteration processes. From Figure 5, the REE geochemistry of the sampling groups reveals three (3) distinct patterns indicative of their provenance, showing which groups are quite similar to each other. In general, all of the patterns follow a trend of relatively depleted LREE and higher values of HREE. The level of disparity between the light and heavy REE is what differentiates the patterns from each sampling group.

These behaviors of REE can be related to the weathering processes in the area (fluvial action and chemical weathering processes). However, since REEs are generally immobile elements (Middelburg et al. 1988) except for deep/strong weathering processes (Aide and Aide 2012; Chang et al. 2016), these REE trends can only be attributed to the original bedrock composition.

Samples from the pit lake, Tagburos River, nearby rivers, and soils showed very similar upper continental crust (UCC)-normalize REE patterns and they have the highest disparity between levels of HREE and LREE. The heavy REE (Eu to $\mathrm{Lu}$ ) is in the range of 0.8-1.1, which coincides very closely to the values of the upper continental crust, while the light REEs go from 0.2 to 0.6 , from La to $\mathrm{Sm}$, respectively. These results for the four groups involved strongly suggest their same provenance and characteristics based on REE geochemistry. The REE fractionation for these four sampling groups can be correlated with two factors: (1) alteration processes that occurred due to hydrothermal activity that brought about the mercury mineralization, and/or (2) weathering processes. The same signature between the river sediments and the soil cover suggest that weathering processes related to fluvial action do not affect the REEs in the sediments. From the results, there is a higher degree of depletion of light rare earth elements than HREE. This is analogous to the trend of REE concentration in the phyllic alteration zone from hydrothermal processes in the Rangan area volcanic belt in Iran (Parsapoor et al. 2009). Heavy REE already has fixed a concentration in the crystal lattice of silicic minerals in these zones, such as quartz. Since there is no known secondary mineral formed from hydrothermal alteration that can incorporate LREE in their structure, LREE depletion can prevail.

The values for Honda Bay wharf and mine waste calcine display almost horizontal lines, indicating REE trends similar to the crustal average values, albeit diluted approximately 10 times. These two sampling groups are allegedly

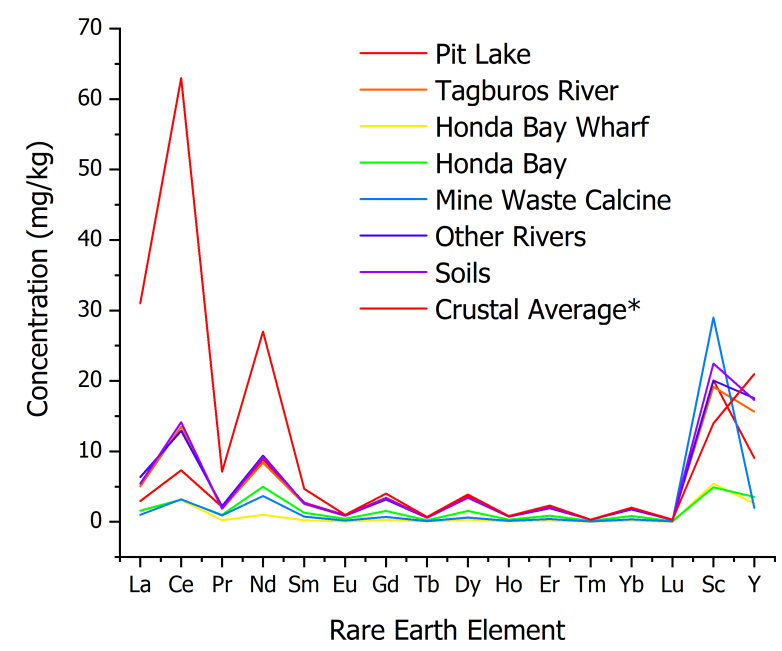

FIGURE 3. Comparison of REE concentrations in sampling groups versus crustal average. 
TABLE 3. REES and radionuclide concentrations of sediment samples collected in different zones in the vicinity of PQMI lake as opposed to crustal average.

\begin{tabular}{|c|c|c|c|c|c|c|c|c|c|}
\hline $\begin{array}{l}\text { Trace element } \\
(\mathrm{mg} / \mathrm{kg})\end{array}$ & Pit lake & $\begin{array}{l}\text { Tagburos } \\
\text { River }\end{array}$ & $\begin{array}{c}\text { Honda Bay } \\
\text { wharf }\end{array}$ & Honda Bay & $\begin{array}{c}\text { Mine waste } \\
\text { calcine }\end{array}$ & Other rivers & $\begin{array}{l}\text { Surrounding } \\
\text { soils }\end{array}$ & $\begin{array}{c}\text { Crustal } \\
\text { average* }\end{array}$ & $\begin{array}{c}\mathrm{Cl} \\
\text { Chondrite }^{* *}\end{array}$ \\
\hline La & 2.94 & 5.03 & 1.54 & 1.60 & 1.01 & 6.34 & 5.39 & 31.00 & 0.237 \\
\hline $\mathrm{Ce}$ & 7.33 & 13.53 & 3.11 & 3.17 & 3.21 & 12.91 & 14.15 & 63.00 & 0.613 \\
\hline $\operatorname{Pr}$ & 2.15 & 1.85 & 0.23 & 1.00 & 0.91 & 2.21 & 1.89 & 7.10 & 0.093 \\
\hline $\mathrm{Nd}$ & 8.88 & 8.43 & 0.99 & 4.97 & 3.69 & 9.41 & 9.24 & 27.00 & 0.457 \\
\hline Sm & 2.72 & 2.53 & 0.25 & 1.30 & 0.72 & 2.62 & 2.63 & 4.70 & 0.148 \\
\hline $\mathrm{Eu}$ & 0.94 & 0.85 & 0.08 & 0.43 & 0.21 & 0.88 & 0.92 & 1.00 & 0.056 \\
\hline Gd & 3.42 & 3.19 & 0.29 & 1.56 & 0.69 & 3.17 & 3.33 & 4.00 & 0.199 \\
\hline $\mathrm{Tb}$ & 0.61 & 0.57 & 0.05 & 0.25 & 0.11 & 0.57 & 0.57 & 0.70 & 0.036 \\
\hline Dy & 3.69 & 3.42 & 0.30 & 1.56 & 0.62 & 3.42 & 3.45 & 3.90 & 0.246 \\
\hline Ho & 0.75 & 0.74 & 0.07 & 0.33 & 0.13 & 0.73 & 0.77 & 0.83 & 0.055 \\
\hline Er & 1.98 & 2.02 & 0.19 & 0.87 & 0.39 & 1.95 & 2.07 & 2.30 & 0.160 \\
\hline $\mathrm{Tm}$ & 0.33 & 0.32 & 0.04 & 0.13 & 0.05 & 0.32 & 0.30 & 0.30 & 0.025 \\
\hline $\mathrm{Yb}$ & 1.75 & 1.85 & 0.18 & 0.82 & 0.36 & 1.74 & 1.90 & 2.00 & 0.161 \\
\hline Lu & 0.27 & 0.27 & 0.03 & 0.12 & 0.05 & 0.26 & 0.27 & 0.31 & 0.025 \\
\hline Sc & 20.10 & 19.18 & 5.43 & 4.88 & 29 & 20.05 & 22.47 & 14.00 & \\
\hline Y & 9.08 & 15.62 & 2.60 & 3.55 & 1.96 & 17.54 & 17.30 & 21.00 & 1.500 \\
\hline Th & 0.47 & 0.84 & 0.26 & 0.22 & 0.81 & 1.23 & 0.86 & 6.00 & \\
\hline U & 0.22 & 0.39 & 0.50 & 0.36 & 0.27 & 0.33 & 0.21 & 2.70 & \\
\hline
\end{tabular}

*Weng et al. (2015), **McDonough and Sun (1995)

of similar nature, namely waste products of mining activity in the past because some of the mine tailings were used to construct the wharf. All REEs in the two sampling groups lie in the range of 0 to 0.2 and their similar trend supports their same origin and identical characteristics, given that they have the highest concentration of $\mathrm{Hg}$ in all of the sediments. It can be inferred that the calcination of the mined ores that produced these sediments have leached most REEs.

The UCC-normalize REE pattern of the Honda Bay sediments show all HREEs around 0.4 while the LREEs increase from 0 to 0.3 from La to $\mathrm{Sm}$, respectively. This pattern is an intermediary of the two aforementioned major groups. This probably resulted from the dilution of terrestrial sediments similar to those from the rivers and soil with marine sediments that have relatively lower amounts of REEs.

The minimal concentration of radionuclides in all sampling areas in comparison with the crustal average are re-

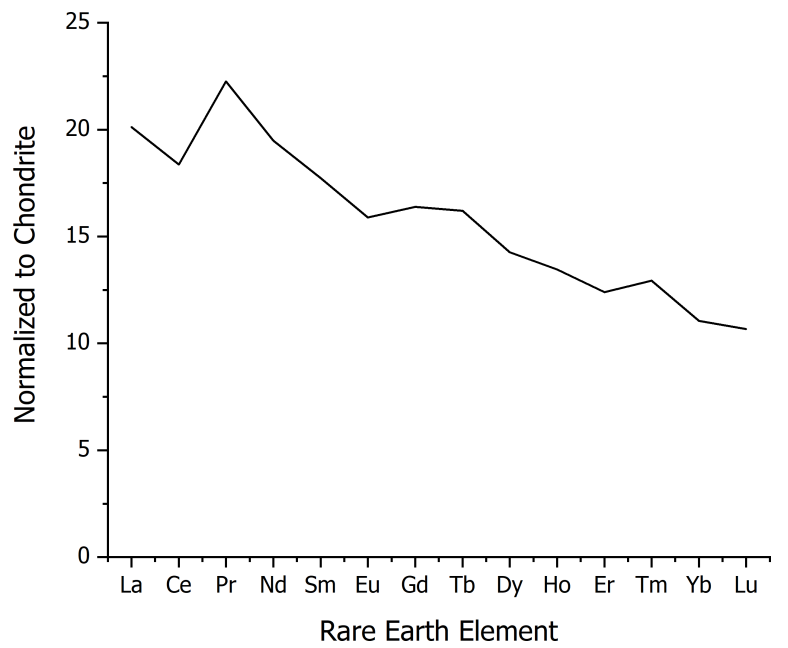

FIGURE 4. Chondrite-normalized REE concentrations in pit lake and rivers. lated to the nature of $\mathrm{U}$ and $\mathrm{Th}$ as incompatible elements. Incompatible elements are those that preferentially stay in the melt during magmatic differentiation and are subdivided into two categories: large ion lithophile elements (LILE) and high field strength elements (HFSE). U and Th belong to the HFSE category and are incompatible because of their high cationic charge. $U$ and Th are enriched in silicic rocks. Since Puerto Princesa City is underlain with ultramafic rocks, $\mathrm{U}(0.21-0.50 \mathrm{mg} / \mathrm{kg})$ and $\mathrm{Th}(0.22-1.23 \mathrm{mg} / \mathrm{kg})$ occur in small amounts compared with the crustal average.

\subsection{Correlation of $\mathrm{Hg}$, other heavy metals, total REE ( $\Sigma \mathrm{REE}$ ) and radioactive elements}

The possible relationships between the trace elements were assessed by linear correlation. The Pearson correlation coefficient $(r)$ was calculated between the $\mathrm{Hg}$, pollut-

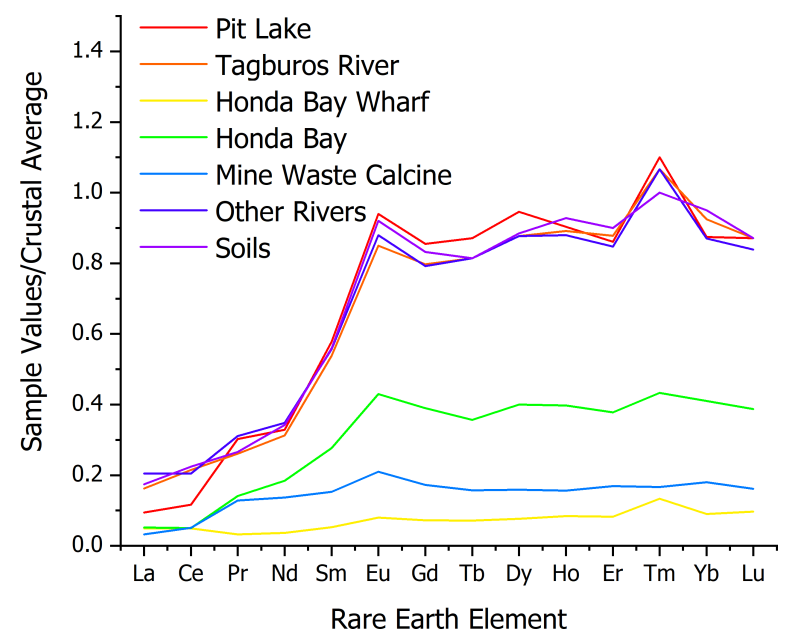

FIGURE 5. Crustal average-normalized REE concentrations in all sampling groups. 
TABLE 4. Pearson correlation coefficients of significant trace elements with each other.

\begin{tabular}{|c|c|c|c|c|c|c|c|c|c|c|}
\hline & Co & $\mathrm{Cr}$ & $\mathrm{Ni}$ & $\mathrm{Fe}$ & $\mathrm{Sb}$ & $\mathrm{Tl}$ & $\mathrm{Hg}$ & $\Sigma \mathrm{REE}^{*}$ & Th & U \\
\hline As & -0.805 & -0.074 & -0.604 & 0.121 & 0.977 & 0.957 & 0.777 & -0.657 & -0.648 & 0.145 \\
\hline Co & & 0.438 & 0.902 & 0.372 & -0.685 & -0.610 & -0.317 & 0.570 & 0.749 & -0.654 \\
\hline $\mathrm{Cr}$ & & & 0.555 & 0.944 & 0.097 & 0.116 & 0.488 & -0.468 & 0.031 & -0.431 \\
\hline $\mathrm{Ni}$ & & & & 0.490 & -0.501 & -0.426 & -0.057 & 0.348 & 0.526 & -0.580 \\
\hline $\mathrm{Fe}$ & & & & & 0.306 & 0.350 & 0.647 & -0.445 & 0.071 & -0.609 \\
\hline $\mathrm{Sb}$ & & & & & & 0.992 & 0.867 & -0.679 & -0.572 & -0.029 \\
\hline $\mathrm{Tl}$ & & & & & & & 0.886 & -0.611 & -0.508 & -0.137 \\
\hline $\mathrm{Hg}$ & & & & & & & & -0.667 & -0.510 & -0.291 \\
\hline ¿REE & & & & & & & & & 0.669 & -0.352 \\
\hline Th & & & & & & & & & & -0.564 \\
\hline
\end{tabular}

* $\Sigma$ REE refers to the total amount of rare earth elements ( $\mathrm{La}, \mathrm{Ce}, \mathrm{Pr}, \mathrm{Nd}, \mathrm{Sm}, \mathrm{Eu}, \mathrm{Gd}, \mathrm{Tb}, \mathrm{Dy}, \mathrm{Ho}, \mathrm{Er}, \mathrm{Tm}, \mathrm{Yb}, \mathrm{Lu}, \mathrm{Sc}, \mathrm{and} \mathrm{Y}$ ).

ing heavy metals (As, Co, Cr, Ni, Sb, and Tl), iron (Fe), REEs, and the radioactive elements (Table 4). Fe was considered in order to assess the possible interaction with reactive $\mathrm{Fe}$ and iron hydroxide $(\mathrm{Fe}-\mathrm{OH})$ phases. Fe and $\mathrm{Cr}$ had a very strong positive correlation $(0.9<r<1)$ because of their cooccurrence in mineral phases like chromite, which is abundant in the ultramafic bedrock. Nickel and cobalt also exhibit a very strong positive correlation as these two can be associated together in lateritic soils (Putzolu et al. 2018). As, $\mathrm{Pb}$, and $\mathrm{Tl}$ have a three-way very strong positive relationship with each other while they all have a strong positive correlation $(0.7<r<0.9)$ with $\mathrm{Hg}$ that probably occurred as accessory metals with $\mathrm{Hg}$ in the deposit given their association. Each of the REE (except Sc) along with total REE content for the sampling groups have close $r$ values with respect to $\mathrm{Hg}$, where they exhibit a strong negative correlation. The REEs tend to deplete with the increase in $\mathrm{Hg}$ pollution in the sediments that could indicate their nonaffinity to $\mathrm{Hg}$ during its deposition. The radioactive elements, with their low concentration in all the samples tend to generally not associate with any of the investigated elements except for Th and Co.

\subsection{Recommendation to control the impact of pollutants in the PQMI mine area}

These findings confirmed the contamination of heavy metals in the soil, such as $\mathrm{Ni}, \mathrm{Cr}, \mathrm{Mn}$, and $\mathrm{Hg}$, which are inherent in the geology of the area. In order to curb the elevated values of these elements, particularly $\mathrm{Hg}$, soil remediation techniques such as phytoremediation is recommended as a low investment, in situ type of solution. Revegetation of the mined-out area with hyperaccumulator species endemic to the pit lake vicinity is yet another area of study. The above mining rehabilitation techniques, if implemented, can reduce soil erosion and soil particle suspension.

\section{CONCLUSIONS}

This study presented the characteristics of heavy metals, rare earth elements, and radioactive elements in the soil and sediments of the abandoned mercury mine in Puerto Princesa City, Palawan. Aside from $\mathrm{Hg}$, there are considerably higher concentrations of $\mathrm{Ni}, \mathrm{Cr}$, and $\mathrm{Mn}$ in the area due to its geology, particularly following the lithology traversed by the Tagburos River. The presence of ultramafic rocks of Palawan Ophiolite in the upstream portion of Tagburos River explains the high $\mathrm{Cr}$ and $\mathrm{Ni}$ concentrations while the high Mn content of the sediment samples can be attributed to the occurrence of interbedded red chert and dark manganiferous chert in the northeast of the pit lake. High concentrations of $\mathrm{Ni}, \mathrm{Cr}$, and $\mathrm{Hg}$ are manifested with the calculated highest contamination factor among the measured trace elements. The areas dumped with mine wastes were distinguished by their very depleted REE signature as opposed to the similar patterns exhibited by all other terrestrial sediments due to their parent rock origin. Past mining activities had an impact on the REE distribution in the area by leaching it in the process and REEs tend to deplete with the increase in Hg pollution in the sediments, which could indicate their non-affinity to $\mathrm{Hg}$ during its deposition. REEs were found to have a negative correlation with $\mathrm{Hg}$. The concentration of $\mathrm{U}$ and $\mathrm{Th}$ found in the soil and sediments were within expected values in an ultramafic area and disturbance of the ground from mining did not enhance their concentrations. Mine rehabilitation activities, such as revegetation to reduce soil erosion and soil particle suspension and phytoremediation to remove heavy metals in soil, need to be implemented based on the results of this study.

\section{ACKNOWLEDGMENTS}

The authors acknowledge the Department of Science and Technology, the Philippine Council for Industry, Energy, and Emerging Technology Research and Development (DOST-PCIEERD) for the monitoring of project. This work was supported by the Department of Science and Technology - Grants-in-Aid Program (Research Grant No. 6873).

\section{AUTHORS' CONTRIBUTIONS}

JS, CRG: conception and design of study and supervision, sample acquisition, analysis, interpretation of data. AT, RR: sample acquisition, analysis, interpretation of data, drafting the manuscript. All authors have read and approved the final version of the manuscript.

\section{COMPETING INTERESTS}

The authors declare that there is no conflict or competing interests regarding the publication of this manuscript.

\section{REFERENCES}

Aide MT, Aide C. 2012. Rare earth elements: their importance in understanding soil genesis. ISRN Soil Sci. 2012:1-11. doi:10.5402/2012/783876. 
Antonio L, Aguilar O, De Luna E, Palaganas U, Maikooksoong C. 1976. Geology and mineral resources of Palawan Province. Manila: Bureau of Mines.

Aurelio MA, Forbes MT, Taguibao KJL, Savella RB, Bacud JA, Franke D, Pubellier M, Savva D, Meresse F, Steuer S, Carranza CD. 2014. Middle to Late Cenozoic tectonic events in south and central Palawan (Philippines) and their implications to the evolution of the southeastern margin of South China Sea: evidence from onshore structural and offshore seismic data. Mar Pet Geol. 58:658-673. doi:10.1016/j.marpetgeo.2013.12.002.

Chang C, Li F, Liu C, Gao J, Tong H, Chen M. 2016. Fractionation characteristics of rare earth elements (REEs) linked with secondary $\mathrm{Fe}, \mathrm{Mn}$, and $\mathrm{Al}$ minerals in soils. Acta Geochim. 35(4):329-339. doi:10.1007/s11631-016 -0119-1.

Dey A, Hussain MF, Barman MN. 2018. Geochemical characteristics of mafic and ultramafic rocks from the Naga Hills Ophiolite, India: implications for petrogenesis. Geosci Front. 9(2):517-529. doi:10.1016/j.gsf.2017.05. 006.

Gibaga CRL, Arcilla CA, Hoang N. 2020. Volcanic rocks from the Central and Southern Palawan Ophiolites, Philippines: tectonic and mantle heterogeneity constraints. J Asian Earth Sci X. 4:100038. doi:10.1016/j.jaesx.2020.1 00038.

Gray JE, Greaves IA, Bustos DM, Krabbenhoft DP. 2003. Mercury and methylmercury contents in mine-waste calcine, water, and sediment collected from the Palawan Quicksilver Mine, Philippines. Environ Geol. 43(3):298-307. doi:10.1007/s00254-002-0626-8.

Hakanson L. 1980. An ecological risk index for aquatic pollution control: a sedimentological approach. Water Res. 14(8):975-1001. doi:10.1016/0043-1354(80)90143-8.

McDonough WF, Sun Ss. 1995. The composition of the Earth. Chem Geol. 120(3):223-253. doi:10.1016/0009-2 541(94)00140-4.

Middelburg JJ, van der Weijden CH, Woittiez JRW. 1988. Chemical processes affecting the mobility of major, minor and trace elements during weathering of granitic rocks. Chem Geol. 68(3):253-273. doi:10.1016/0009-2 541(88)90025-3.

Moghadam HS, Stern RJ. 2011. Geodynamic evolution of Upper Cretaceous Zagros ophiolites: formation of oceanic lithosphere above a nascent subduction zone. Geol Mag. 148(5-6):762-801. doi:10.1017/S0016756811000410.

Padrones JT, Imai A, Takahashi R. 2017. Geochemical behavior of rare earth elements in weathered granitic rocks in northern Palawan, Philippines. Resour Geol. 67(3):231-253. doi:10.1111/rge.12123.

Pallister JS, Knight RJ. 1981. Rare-earth element geochemistry of the Samail Ophiolite near Ibra, Oman. J Geo- phys Res: Solid Earth. 86(B4):2673-2697. doi:10.1029/ JB086iB04p02673.

Parsapoor A, Khalili M, Mackizadeh MA. 2009. The behaviour of trace and rare earth elements (REE) during hydrothermal alteration in the Rangan area (Central Iran). J Asian Earth Sci. 34(2):123-134. doi:10.1016/j. jseaes.2008.04.005.

Peña RE. 2008. Lexicon of Philippine stratigraphy, 2008. Mandaluyong City: Geological Society of the Philippines.

Putzolu F, Balassone G, Boni M, Maczurad M, Mondillo N, Najorka J, Pirajno F. 2018. Mineralogical association and $\mathrm{Ni}$-Co deportment in the Wingellina oxide-type laterite deposit (Western Australia). Ore Geol Rev. 97:21-34. doi: 10.1016/j.oregeorev.2018.05.005.

Samaniego J, Gibaga CR, Tanciongco A, Rastrullo R. 2020a. Total mercury in soils and sediments in the vicinity of abandoned mercury mine area in Puerto Princesa City, Philippines. Appl Sci. 10(13):4599. doi:10.3390/app101 34599.

Samaniego J, Gibaga CR, Tanciongco A, Rastrullo R, Mendoza N, Racadio CD. 2020b. Comprehensive assessment on the environmental conditions of abandoned and inactive mines in the Philippines. ASEAN J Sci Technol Dev. 37(2):81-86. doi:10.29037/ajstd.623.

Suggate SM, Cottam MA, Hall R, Sevastjanova I, Forster MA, White LT, Armstrong RA, Carter A, Mojares E. 2014. South China continental margin signature for sandstones and granites from Palawan, Philippines. Gondwana Res. 26(2):699-718. doi:10.1016/j.gr.2013.07.006.

Taylor SR. 1964. Abundance of chemical elements in the continental crust: a new table. Geochim Cosmochim Acta. 28(8):1273-1285. doi:10.1016/0016-7037(64)90129 $-2$.

Weng Z, Jowitt SM, Mudd GM, Haque N. 2015. A detailed assessment of global rare earth element resources: opportunities and challenges. Econ Geol. 110(8):1925-1952. doi:10.2113/econgeo.110.8.1925.

Williams TM, Weeks JM, Jr AA, Miranda CR. 1999. Assessment of mercury contamination and human exposure associated with coastal disposal of waste from a cinnabar mining operation, Palawan, Philippines. Environ Geol. 39(1):51-60. doi:10.1007/s002540050436.

Yumul GP, Dimalanta CB, Marquez EJ, Queaño KL. 2009. Onland signatures of the Palawan microcontinental block and Philippine mobile belt collision and crustal growth process: a review. J Asian Earth Sci. 34(5):610623. doi:10.1016/j.jseaes.2008.10.002.

Zerda R. 1972. Geological investigation and mineral verification of 11 lode claims of Palawan Quicksilver Mines Inc., located at Sta. Lourdes, Puerto Princesa City, Palawan. Manila: Bureau of Mines. 